\title{
PENINGKATAN PRODUKTIVITAS IKAN LELE (Clarias sp.) SISTEM BIOFLOK DI PESANTREN MODERN DARUL MA'ARIF LEGOK, INDRAMAYU
}

\section{ENHACEMENT OF CATFISH (Clarias sP.) PRODUCTIVITY IN BIOFLOC SYSTEM AT DARUL MA'ARIF ISLAMIC BOARDING SCHOOL LEGOK, INDRAMAYU}

\author{
Asy Syafa Yumna, Djumbuh Rukmono, Amyda Suryati Panjaitan\#, dan Mugi Mulyono \\ Sekolah Tinggi Perikanan \\ Jl. AUP Pasar Minggu-Jakarta Selatan 12520 \\ E-mail: amyda.panjaitan@kkp.go.id
}

(Diterima: 13 September 2019; Diterima setelah perbaikan: 20 November 2019; Disetujui: 20 November 2019)

\begin{abstract}
ABSTRAK
Ikan lele merupakan sumber protein hewani yang bernilai ekonomis dan kebutuhannya terus meningkat setiap tahun. Keunggulan teknologi bioflok yang mampu menggenjot produktivitas ikan menjadi lebih tinggi dengan penggunaan lahan yang tidak terlalu luas. Tujuan penelitian adalah mengevaluasi teknis budidaya ikan lele sistem bioflok, implementasi intervensi untuk meningkatkan produktivitas budidaya ikan lele sistem bioflok, mengevaluasi performa kinerja budidaya ikan lele sistem bioflok setelah implementasi intervensi, menganalisis finansial budidaya ikan lele sistem bioflok. Intervensi berdasarkan prioritas usulan pemecahan masalah yakni penambahan kuantitas blower dan titik aerasi, pembuatan water level, sampling mingguan dan membeli benih bersertifikat. Hasil penelitian menunjukkan rata-rata performansi kinerja budidaya dan produktivitas mengalami peningkatan, sedangkan rasio konversi pakan mengalami kenaikan. Implementasi yang dilakukan mampu meningkatkan dari produktivitas sebesar Rp. 526.687 (sebelum intervensi) menjadi sebesar Rp. 1.242.187 (setelah intervensi) dengan tingkat kelangsungan hidup sebelum intervensi $46 \%$, setelah intervensi sebesar $71 \%$. Berdasarkan hasil analisis finansial, layak untuk dilanjutkan dengan R/C Ratio sebelum intervensi 0,96, setelah intervensi sebesar 1,06.
\end{abstract}

KATA KUNCI: Ikan lele; bioflok; intervensi; tingkat kelangsungan hidup

\begin{abstract}
Catfish is a valuable source of animal protein and its needs continue to increase every year. The advantages of biofloc technology are able to boost fish productivity to be higher with the use of land that is not too broad. The research objectives are to evaluate the technical techniques of biofloc catfish culture, implementation of interventions to increase the productivity of biofloc catfish culture, evaluate the performance of biofloc catfish culture performance after the implementation of the intervention, financially analyze the biofloc catfish culture system. Interventions based on the priority of proposed solutions to the problem of adding the quantity of blowers and aeration points, making water levels, weekly sampling and buying certified seeds. The results showed the average performance of aquaculture performance and productivity had increased, while the feed conversion ratio had increased. The implementation has been able to increase the productivity of Rp. 526,687 (before the intervention) amounted to Rp. 1,242,187 (after the intervention) with a survival rate before intervention of $46 \%$, after the intervention of $71 \%$. Based on the results of financial analysis it is feasible to proceed with $\mathrm{R} / \mathrm{C}$ Ratio before intervention 0.96 , after the intervention of 1.06 .
\end{abstract}

KEYWORDS: Catfish; biofloc; intervention; survival rate

\footnotetext{
\# Korespondensi: Sekolah Tinggi Perikanan
}

E-mail: amyda.panjaitan@kkp.go.id 


\section{PENDAHULUAN}

Sumber daya perikanan di Indonesia sangat kaya dan potensial, baik di wilayah darat, pantai, maupun laut Potensi tersebut didukung kondisi alam yang beragam dan menguntungkan untuk akuakultur (Irianto \& Soesilo, 2007), sehingga memberi peluang untuk pengembangan komoditas budidaya yang beragam pula (Sari et al., 2017). Berdasarkan tingkatan teknologi yang diterapkan, budidaya dapat dilakukan secara intensif, semi intensif dan tradisional (Irianto \& Soesilo, 2007). Beberapa permasalahan yang teridentifikasi dengan metode fishbone berdasarkan pendekatan pada $4 \mathrm{M}$ pada metode kerja karena tidak mengimplementasikan SOP secara keseluruhan pada proses produksi. Hal ini menyebabkan terjadinya penurunan produktivitas yang berdampak pada profitabilitas, sehingga perlu dilakukan penerapan kembali SOP serta beberapa usulan intervensi untuk dapat meningkatkan produktivitas dan profitabilitas usaha pembesaran ikan lele sistem bioflok.

Ikan lele merupakan sumber protein hewani yang bernilai ekonomis dan kebutuhannya terus meningkat setiap tahun (Hermawan et al., 2014). Produksi ikan lele dari hasil budidaya secara nasional pada tahun 2011 sebesar 337.557 ton dan pada tahun 2015 mengalami kenaikan menjadi 722.623 ton. Selain itu, meskipun $70 \%$ masyarakat Indonesia mengonsumsi ikan lebih dari angka harapan sebesar $30,14 \mathrm{~kg} / \mathrm{kapita} / \mathrm{tahun}$, upaya pemenuhan target konsumsi ikan sebesar 50,65 $\mathrm{kg} / \mathrm{kapita} / \mathrm{tahun}$ pada tahun 2018 dan tahun selanjutnya harus tetap diperjuangkan (DJPB, 2018) sehingga perlu adanya inovasi agar produksi meningkat.

Intensifikasi adalah salah satu alternatif untuk meningkatkan produksi dengan meningkatkan padat penebaran, penggunaan lahan yang terbatas, manajemen lingkungan yang baik serta penggunaan pakan buatan (Hermawan et al., 2014). Namun, intensifikasi budidaya ikan lele dapat memberikan dampak negatif bagi kesehatan lingkungan (Imron et al., 2014) yang disebabkan limbah organik dari sisa pakan dan kotoran, yang umumnya didominasi oleh senyawa nitrogen anorganik beracun (Hermawan et al., 2014).

Teknologi bioflok merupakan salah satu pemecah masalah lingkungan dan dapat meningkatkan produksi budidaya (Imron et al., 2014). Sistem bioflok menjadi solusi masalah limbah, yakni pemanfaatan amonia oleh bakteri heterotrof menjadi bahan makanannya dan diubah menjadi flok (Putri et al., 2015; Nuari et al., 2016). Penerapan sistem ini dapat meningkatkan kemampuan sistem akuakultur dalam mengurangi limbah budidaya, serta dapat meningkatkan biomassa ikan yang memakan flok (Septiani et al., 2014). Apabila diaplikasikan dengan tepat maka teknologi bioflok dapat meminimalisir penggantian air atau bahkan tidak ada penggantian air dalam sistem budidaya sehingga teknologi ini ramah lingkungan (Sudaryati et al., 2017).

Teknologi bioflok adalah teknologi berdasarkan pertumbuhan bakteri heterotrof secara intensif, yang mengonsumsi karbon organik dan mendekomposisi nitrogen anorganik tergantung pada perbandingan karbon dan nitrogen diatur oleh seimbangnya penambahan karbon yang dicapai dengan menambahkan karbon organik dan menghasilkan protein mikroba sebagai makanan ikan (Phulia et al., 2012). Keunggulan teknologi bioflok yang mampu menggenjot produktivitas ikan menjadi lebih tinggi dengan penggunaan lahan yang tidak terlalu luas dan hemat sumber daya air ini kemudian mendorong Kementerian Kelautan dan Perikanan (KKP) untuk merealisasikan program dukungan usaha budidaya ikan lele sistem bioflok untuk 73 pesantren di 15 provinsi di Indonesia (DJPB, 2018).

\section{BAHAN DAN METODE}

Penelitian dilaksanakan pada tanggal 4 Maret 2019 sampai 1 Juni 2019 yang berlokasi di Pesantren Modern Darul Ma'arif Legok, Jalan Suryanegara Nomor 1, Desa Legok, Kecamatan Lohbener, Kabupaten Indramayu, Provinsi Jawa Barat. Analisis kualitas air mingguan dilaksanakan di Laboratorium Dinas Kelautan dan Perikanan Indramayu.

\section{Rancangan Penelitian}

Penelitian dengan melakukan intervensi seperti menebar benih yang bersertifikasi, menambah kuantitas blower dan titik aerasi, membuat water level serta melakukan sampling mingguan. Penelitian diawali dengan persiapan kolam bundar bervolume $5 \mathrm{~m}^{3}$ yakni dengan mencuci kolam menggunakan sikat. Kemudian dilakukan pembilasan dan pengeringan selama $24 \mathrm{jam}$. Blower yang digunakan sebanyak dua buah dengan kapasitas total 24.000 liter/jam atau 286 liter/jam/titik aerasi. Lalu dilakukan pengisian media setinggi $70 \mathrm{~cm}$ dan aplikasi pembentuk flok yakni pemberian kapur pertanian (kaptan) $200 \mathrm{~g} / \mathrm{m}^{3}$, garam krosok $3 \mathrm{~kg} / \mathrm{m}^{3}$ dan molase $250 \mathrm{ml} / \mathrm{m}^{3}$. Benih yang digunakan selama penelitian adalah 6.000 ekor benih ikan lele mutiara dari Balai Pemuliaan Ikan Sukamandi berukuran 2-3 cm (1,6 g/ekor) dan 6.000 ekor dari induk ikan lele Sangkuriang dari Balai Benih Perikanan Budidaya Air Tawar (BBPBAT) Sukabumi yang dipelihara oleh pembudidaya setempat berukuran $9-10 \mathrm{~cm}$ (6,3 g/ekor). Sebelum ditebar, benih diambil sampel untuk diukur bobot dan panjangnya kemudian disortir dan diaklimatisasi. Benih ditebar dengan kepadatan 600 ekor $/ \mathrm{m}^{3}$. Benih diberi pakan pellet terapung dengan 
kadar protein $31-33 \%$ yang difermentasi dengan probiotik 150 liter untuk $1 \mathrm{~kg}$ pakan. Pengamatan pertumbuhan dilakukan seminggu sekali dengan mengukur bobot dan panjang ikan. Pengukuran kualitas air dilakukan empat kali sehari untuk kadar oksigen, $\mathrm{pH}$ dan suhu serta seminggu sekali untuk amonia, amonium, nitrat dan nitrit. Panen dilakukan pada size 11-12 atau 83-100 g/ekor.

\section{Parameter yang diukur}

Parameter penelitian yang diamati dan diukur dalam penelitian ini antara lain performa kinerja budidaya, kualitas air dan analisis finansial. Performa kinerja budidaya yang diamati meliputi produktivitas, Survival Rate (SR), Feed Convertion Ratio (FCR) dan Average Daily Growth (ADG). Kualitas air yang diamati meliputi amonia, amonium, oksigen terlarut, nitrit, nitrat, $\mathrm{pH}$ dan suhu, sedangkan analisis finansial yang diamati meliputi analisis laba rugi dan R/C Ratio. Rumus yang digunakan adalah sebagai berikut.

Tingkat kelangsungan hidup ikan atau Survival Rate (SR) diperoleh dengan mengikuti rumus menurut Khobir et al. (2016), sebagai berikut :

$$
\mathrm{SR}=\frac{\mathrm{Nt}}{\mathrm{No}} \times 100 \%
$$

SR $=$ Kelangsungan hidup ikan (\%).

$\mathrm{Nt}=$ Jumlah ikan pada akhir pengamatan (ekor).

No = Jumlah ikan pada awal pengamatan (ekor).

Rasio Konversi pakan atau Feed Convertion Ratio (FCR) dihitung menggunakan rumus menurut Aksungur et al. (2007), sebagai berikut :

$$
\mathrm{FCR}=\frac{\Sigma \mathrm{fk}}{(\mathrm{Wt}-\mathrm{Wo})+\mathrm{m}}
$$

W0 = Berat ikan hidup mula-mula (g)

$\mathrm{Wt}=$ Berat ikan hidup saat ini $(\mathrm{g})$

$\Sigma f \mathrm{k}=$ Berat pakan yang digunakan dalam periode tersebut (g)

$\mathrm{m} \quad=$ Berat ikan yang mati $(\mathrm{g})$.

Rata-rata pertumbuhan harian atau Average Daily Growth (ADG) ikan lele dihitung menggunakan penghitungan pertumbuhan berat dan penghitungan pertumbuhan panjang. Rata-rata pertumbuhan berat dihitung menggunakan rumus menurut Darmawan (2007) sebagai berikut :

$$
\mathrm{ADG}\left(\frac{\mathrm{g}}{\text { ekor }} \text { /hari }\right)=\frac{\mathrm{ABW} 2-\mathrm{ABW} 1}{\mathrm{t}}
$$

ABW1 = Berat rata-rata sampling pertama atau sebelumnya (g/ekor)
ABW2 $=$ Berat rata-rata sampling kedua atau berikutnya ( $\mathrm{g} / \mathrm{ekor}$ ).

$\mathrm{t} \quad=$ Rentang waktu antar sampling

Untuk menghitung total berat ikan atau biomassa menggunakan rumus Darmawan (2007) sebagai berikut:

Biomassa $(\mathrm{kg})=$ berat rata - rata $\left(\frac{\mathrm{g}}{\text { ekor }}\right) \times$ populasi (ekor)

Rumus yang digunakan untuk menghitung laba atau rugi suatu perusahaan menurut Mas'ud (2012) adalah sebagai berikut :

\section{Laba/Rugi= Pendapatan-BiayaTotal}

Untuk menghitung $R / C$ Ratio, rumus yang digunakan menurut Yulinda (2012) sebagai berikut :

$$
\mathrm{R} / \mathrm{C} \text { Ratio }=\frac{\text { Penerimaan }}{\text { Biaya Produksi }}
$$

\section{Analisis Data}

Perolehan data performa kinerja budidaya (SR, FCR, $\mathrm{ADG}$ ) dan data finansial (analisis laba/rugi dan R/C Ratio) ditampilkan dalam bentuk grafik dan tabel dan dianalisis berdasarkan statistik deskriptif.

\section{HASIL DAN PEMBAHASAN}

Panen pertama memang menjadi panen terbesar, tapi bioflok Darul Ma'arif mengalami kesulitan dalam mempertahankan produksinya. Hal ini terbukti pada produktivitas siklus ketiga, yakni mencapai $26,46 \mathrm{~kg} /$ $\mathrm{m}^{3} /$ siklus yang tidak mencapai $50 \%$ dari target yakni $58,4 \mathrm{~kg} / \mathrm{m}^{3} / \mathrm{siklus}$ dengan padat tebar yang sama yakni $600 \mathrm{ekor} / \mathrm{m}^{3}$ (Gambar 1.).

Padat tebar yang sama pada semua siklus, menghasilkan produksi yang berbeda. Pada siklus pertama dilakukan penebaran sebanyak 72.000 ekor pada 24 kolam. Sementara itu pada siklus ketiga dilakukan penebaran sebanyak 32.000 pada 10 kolam. Sedangkan pada siklus keempat dan kelima jumlah yang ditebar semakin sedikit yakni sebanyak 6.000 ekor setiap siklusnya. Apabila dibandingkan dengan target produksi yang ada yakni $68 \mathrm{~kg} / \mathrm{m}^{3} / \mathrm{siklus}$, produktivitas yang dihasilkan masih cukup jauh dan belum pernah memenuhi target produksi.

Faktor-faktor yang menyebabkan rendahnya produktivitas pada siklus ketiga telah diidentifikasi menggunakan analisis fishbone, meskipun belum mencapai target produksi dan masih jauh dari siklus pertama, pada siklus keempat dan kelima produktivitas berhasil kembali ditingkatkan setelah dilaksanakannya intervensi. 


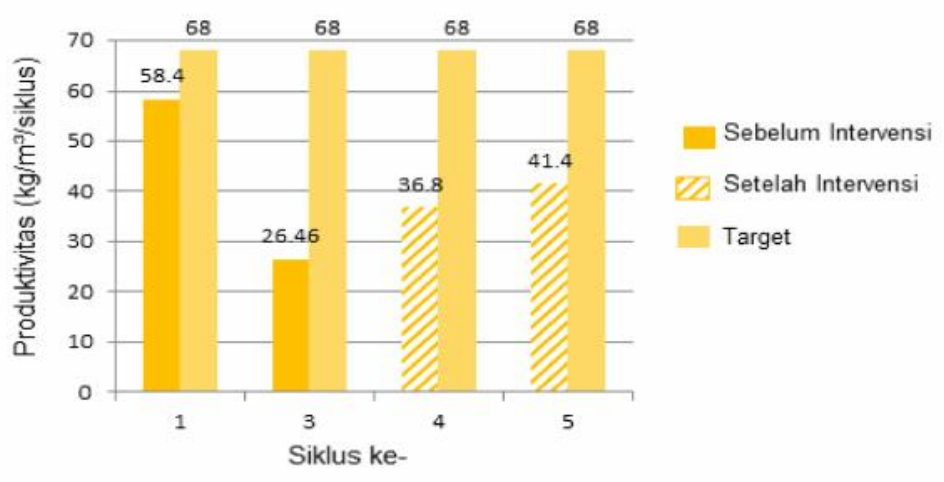

Gambar 1. Produktivitas panen pada saat penelitian dan intervensi

Figure 1. Harvest productivity at the time of research and intervention

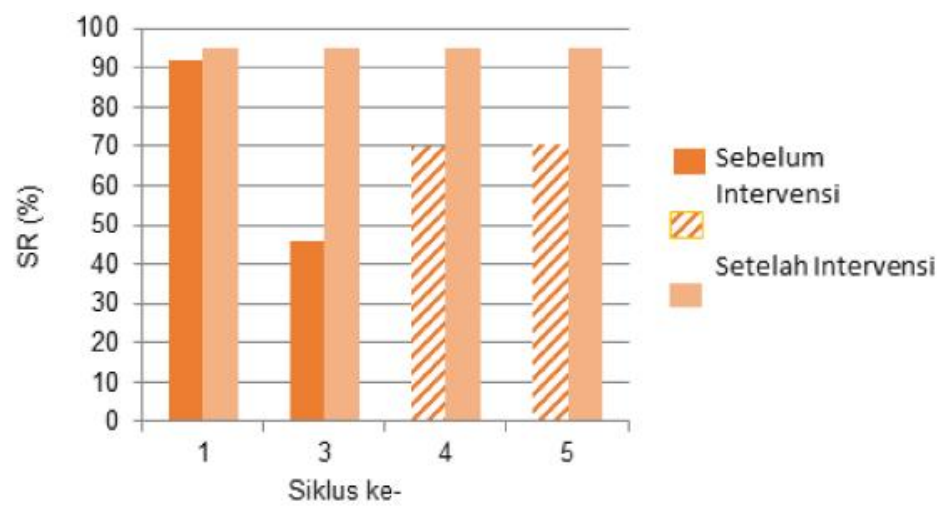

Gambar 2. Persentasi tingkat kehidupan pada saat penelitian dan intervensi.

Figure 2. Percentage of life level at the time of research and intervention.

Tingkat kelangsungan hidup atau survival rate(SR) yang dihasilkan sangat beragam dari siklus pertama hingga siklus kelima. Pada siklus pertama tingkat kelangsungan hidup 92\% yakni dengan selisih 3\% dari target produksi sebesar $95 \%$ (Gambar 2.), namun pencapaian tersebut tidak dapat dipertahankan, karena terjadi penurunan tingkat kelangsungan hidup pada siklus ketiga. Sedangkan, pada siklus kedua tingkat kelangsungan hidup yang dihasilkan tidak diketahui dikarenakan tidak ada pembukuan ataupun dokumentasi oleh teknisi ataupun oleh pimpinan pesantren.

Tingkat kelangsungan hidup ikan lele mengalami penurunan pada siklus ketiga dari $92 \%$ menjadi $46 \%$. Setelah dilakukan intervensi pada penelitian yakni pada siklus keempat dan kelima, tingkat kelangsungan hidup dapat ditingkatkan menjadi 71\%. Walaupun masih jauh dari target produksi yakni $95 \%$ dan tidak sesuai berdasarkan Windriani (2017), yang menyatakan bahwa kelangsungan hidup ikan lele dengan sistem bioflok dapat mencapai $>90 \%$, penerapan intervensi yang dilakukan telah mengurangi jumlah kematian ikan dengan selisih sebelum intervensi dengan setelah intervensi sebanyak $25 \%$.
Feed Convertion Ratio (FCR) atau rasio konversi pakan belum mencapai target produksi yang dijadikan acuan. Nilai rasio konversi pakan sejak siklus pertama hingga siklus kelima masih melebihi satu, sedangkan target produksi yang ditetapkan adalah menapatkan nilai rasio konversi pakan kurang dari satu, yang artinya jumlah pakan yang dikeluarkan harus lebih sedikit dari berat yang dihasilkan untuk menekan biaya produksi.

Seharusnya, teknologi bioflok dapat menurunkan Feed Convertion Ratio (FCR) serta meningkatkan efisiensi pakan (Rizal et al., 2018). Sedangkan, menurut Windriani (2017), nilai konversi pakan atau Feed Convertion Ratio (FCR) ikan lele Sangkuriang berada pada kisaran 0,8-1 bahkan dapat ditekan menjadi 0,7. Feed Convertion Ratio (FCR) atau rasio konversi pakan sejak siklus pertama hingga siklus kelima belum pernah mencapai target produksi yakni $<1$ dan terjadi peningkatan pada siklus ketiga (Gambar 3.). Nilai rasio konversi pakan yang meningkat pada siklus ketiga disebabkan oleh kurangnya pengetahuan teknisi dalam pemberian pakan, dibuktikan dengan tidak dilakukannya pengukuran atau penimbangan pakan. Sehingga, pakan yang digunakan tidak terhitung 


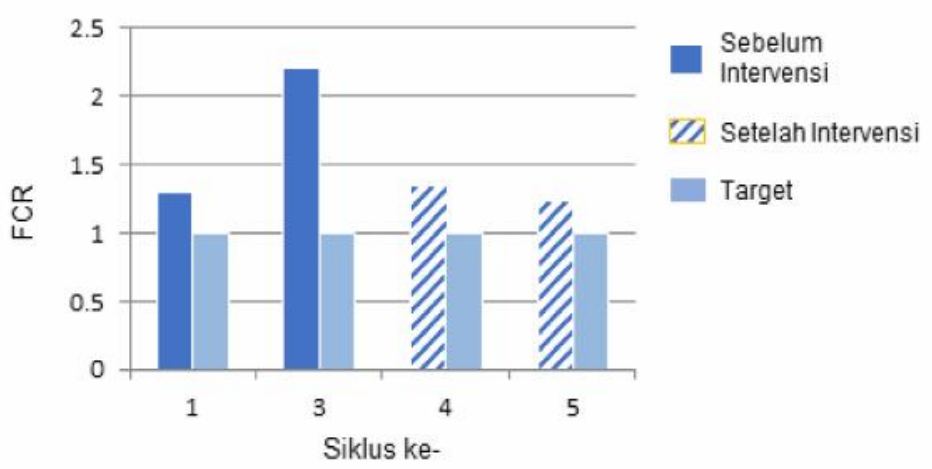

Gambar 3. Rasio konversi pakan sebelumdan setelah intervensi.

Figure 3. Feed conversion ratio before and after intervention.

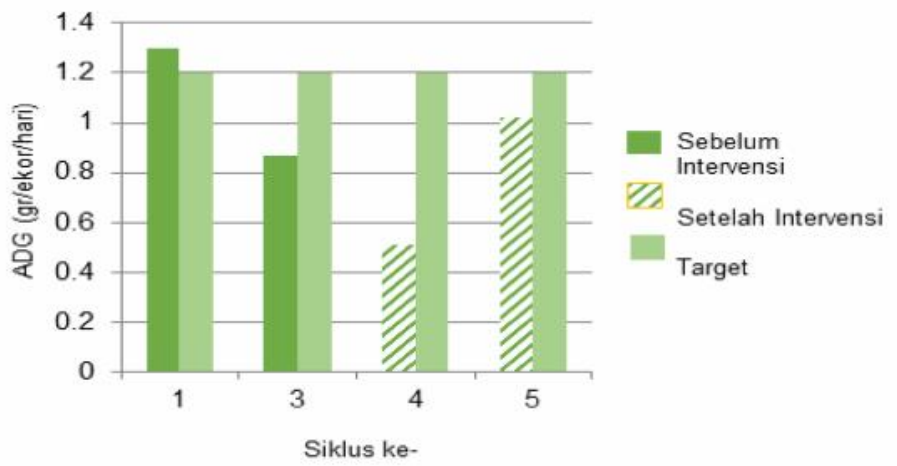

Gambar 4. Pertumbuhan harian sebelum dan setelah intervensi.

Figure 4. Daily growth with interventions in the study.

berdasarkan biomassa ikan, menyebabkan pakan yang diberikan tidak sepenuhnya termakan oleh ikan.

Perlakuan pemberian probiotik Bacillus sp. dan Staphylococcus sp. memiliki nilai Feed Convertion Ratio (FCR) yang paling kecil sedangkan yang tidak dilakukan pemberian probiotik memiliki nilai Feed Convertion Ratio (FCR) yang paling besar. Semakin kecil nilai konversi pakan maka semakin efektif pakan yang diberikan sehingga semakin tinggi nutrien pakan yang tercerna dan semakin besar kemungkinan nutrien tersebut dimanfaatkan oleh ikan untuk pertumbuhannya dan menurunkan porsi nutrien yang akan terbuang ke lingkungan. Semakin tinggi Feed Convertion Ratio (FCR) maka pakan yang dibutuhkan untuk pemeliharaan semakin besar sehingga tidak efisien dalam penggunaan pakan yang tidak sebading dengan pertumbuhan berat ikan (Husain et al., 2014; Hermawan et al., 2014).

Tingkat efisiensi penggunaan pakan yang terbaik akan dicapai pada nilai perhitungan konversi pakan terendah, yang mengakibatkan energi yang diperoleh pada ikan lele lebih banyak digunakan untuk pertumbuhan, sehingga ikan dengan pemberian pakan yang sedikit diharapkan memperoleh laju pertumbuhan yang meningkat. Faktor yang mempengaruhi tinggi rendahnya efisiensi pakan adalah jenis sumber nutrisi dan jumlah dari masing-masing komponen sumber nutrisi dalam pakan tersebut.Jumlah dan kualitas pakan yang diberikan kepada ikan berpengaruh terhadap pertumbuhan ikan. Semakin tinggi nilai efisiensi pakan maka respon ikan terhadap pakan tersebut semakin baik yang ditunjukkan dengan pertumbuhan ikan yang cepat (Hariani \& Purnomo, 2017). Selain itu, adanya penumpukan bahan organik pada media budidaya yang tidak terdegradasi secara optimal dapat menyebabkan kadar amonia yang cukup tinggi pada media budidaya. Penurunan kualitas air pada media budidaya ini membuat ikan menjadi stres dan kehilangan nafsu makan (Sukoco et al., 2016).

Hasil rata-rata Average Daily Growth (ADG) atau rata-rata pertumbuhan harian ikan lele mengalami penurunan yang sangat tajam pada siklus ketiga dan keempat.

Terjadi rata-rata pertumbuhan harian yang sangat lambat pada siklus ketiga (Gambar 4.). Hal ini dikarenakan penggunaan pakan berprotein rendah pada fase akhir lele mendekati panen yakni $14 \%$. Menurut Romadhon et al. (2013), protein pada pakan seharusnya pada kisaran 20-35\%. Pada siklus keempat, rata-rata pertumbuhan harian yang lambat terjadi 
karena ukuran ikan lele yang ditebar terlalu kecil, yakni 2-3 cm. Berdasarkan Abulias \& Winarni (2014), organ tubuh benih ikan lele yang berukuran relatif kecil belum dapat berfungsi secara optimal, sehingga daya tahan tubuhnya rendah dan mudah terserang penyakit. Selain itu, transportasi yang terlalu lama saat penebaran membuat ikan sulit beradaptasi dengan lingkungan sehingga terjadi kematian yang tinggi pada awal penebaran dan kondisi ikan yang sangat lemah menyebabkan pertumbuhan terhambat. Sedangkan pada siklus kelima, rata-rata pertumbuhan harian kembali meningkat yakni sebesar 1,02 g/ekor/hari.

Hasil perhitungan analisis finansial pada saat penelitian mengalami kerugian pada siklus ketiga dan keempat namun pada siklus kelima mengalami keuntungan. Kerugian tertinggi terjadi pada siklus ketiga sebanyak Rp 59.642.758 dengan analisis R/C Ratio 0,58. Namun, kerugian berkurang pada siklus keempat menjadi Rp. 526.687 dengan R/C Ratio 0,96. Sedangkan pada siklus kelima, produksi berhasil ditingkatkan dan mendapatkan keuntungan sebesar Rp. 1.242.187 dengan R/C Ratio 1,06 (Tabel 1).

Berdasarkan Lumentut \& Hartati (2015), jika R/C Ratio lebih besar dari satu, menandakan bahwa gagasan usaha layak untuk dikerjakan dan jika lebih kecil dari satu gagasan usaha tidak layak untuk dikerjakan. Apabila $R / C$ Ratio sama dengan satu berarti cash inflow sama dengan cash outflow atau impas dimana tidak ada kerugian dan keuntungan.

Tabel 1. Ringkasan Analisis Biaya Finansial (Profitivitas)

Table 1. Summary of Financial Cost Analysis (Profitivity)

\begin{tabular}{|c|c|c|c|}
\hline Indikator & Siklus $3\left(R_{p,-}\right)$ & Siklus $4\left(R_{p,-}\right)$ & Siklus $5\left(R_{p,-}\right)$ \\
\hline A. Biaya Investasi & 125.321 .200 & 125.321 .200 & 125.321 .200 \\
\hline B. Biaya Penyusutan & 14.466 .758 & 14.466 .758 & 14.466 .758 \\
\hline C. Biaya Tidak Tetap & 121.230 .000 & 11.328 .724 & 18.498 .750 \\
\hline D. Biaya Tetap & 20.466 .758 & 1.655 .563 & 1.680 .563 \\
\hline E. Biaya Operasional & 141.696 .758 & 12.984 .287 & 20.179 .313 \\
\hline F. Penjualan & 82.054 .000 & 12.457 .600 & 21.421 .500 \\
\hline G. Analisis Laba/Rugi & -59.642 .758 & -526.687 & 1.242 .187 \\
\hline H. Pendapatan Bersih & - & - & 1.242 .187 \\
\hline I. Analisis R/C Ratio & 0,58 & 0,96 & 1,06 \\
\hline
\end{tabular}

R/C Ratio pada siklus ketiga dan keempat kurang dari satu, sehingga dapat dikatakan usaha tersebut mengalami kerugian dan tidak layak untuk dilanjutkan. Namun, kerugian yang didapatkan pada siklus keempat setelah dilaksanakannya intervensi mengalami penurunan dari siklus sebelumnya. Menurunnya tingkat kerugian dari siklus ketiga hingga siklus keempat dan meningkatnya pendapatan yang menyebabkan keuntungan pada siklus kelima menandakan bahwa intervensi yang dilakukan dapat meningkatkan produktivitas dan mengurangi kerugian yang ada. Namun, intervensi tidak sepenuhnya mempengaruhi produksi karena pada siklus keempat tetap mengalami kerugian. Intervensi yang dilakukan pada siklus keempat dan kelima sama namun terdapat perbedaan pada ukuran benih yang ditebar. Ukuran benih yang ditebar pada siklus keempat sangat kecil yang menyebabkan mortalitas yang tinggi pada awal pemeliharaan sehingga mempengaruhi produksi yang dihasilkan. Selain itu, produksi yang dijalankan belum maksimal karena keuntungan yang didapat pada siklus kelima masih rendah. Hal ini disebabkan Standar Prosedur Operasional (SPO) yang ditetapkan belum sepenuhnya diterapkan karena terbatasnya pengetahuan dan pengalaman teknisi. Selain itu, terbatasnya biaya produksi juga mempengaruhi proses produksi, dikarenakan belum adanya manajemen keuangan yang baik.

\section{KESIMPULAN}

Kesimpulan yang dapat diperoleh yaitu meningkatnya kinerja budidaya diantaranya tingkat kelangsungan hidup (Survival Rate/SR) menjadi 70,4\%, nilai konversi rasio pakan (Feed Convertion Ratio/ FCR) menurun menjadi 1,3 , rata-rata pertumbuhan harian (Average Daily Growth/ADG) meningkat menjadi $1,1 \mathrm{~g} /$ ekor/hari dan peningkatan keuntungan sebesar Rp 1.242.187.

\section{UCAPAN TERIMA KASIH}

Ucapan terima kasih disampaikan kepada Pesantren Modern Darul Ma'arif Legok, Kecamatan Lohbener, Kabupaten Indramayu dan Laboratorium Dinas Kelautan dan Perikanan Indramayu atas fasilitas dan dukungannya pada kegiatan penelitian. 


\section{DAFTAR PUSTAKA}

Abulias, M. N., S. R., D. R. U. \& Winarni, E. T. (2014). Manajemen kualitas media pendederan lele pada lahan terbatas dengan teknik bioflok, Jurnal MIPA, 37(1), pp. 16-21.

Aksungur, N. \& Aksungur, M. \& Akbulut, Bilal \& Kutlu, I.. (2007). Effects of stocking density on growth performance survival and food conversion ratio of turbot (Psetta maxima) in the net cages on the Southeastern coast of the Black Sea. Turkish Journal of Fisheries and Aquatic Sciences. 7. 147-152.

Darmawan, B. D. (2007). Pemanfaatan ekstrak kunyit dan bawang putih sebagai nutrisi tambahan alami pada pakan dan aplikasinya terhadap benih ikan lele dumbo (Clarias gariepinus), Jurnal Sumberdaya Perairan, 1(1), pp. 1-6. doi: ISSN 1978 -1652.

DJPB (Direktur Jenderal Perikanan Budidaya) (2018). Petunjuk teknis penyaluran bantuan pemerintah budidaya ikan lele sistem bioflok. Jakarta: Kementerian Kelautan dan Perikanan Direktorat Jenderal Perikanan Budidaya.

Hariani, D. \& Purnomo, T. (2017). Pemberian probiotik dalam pakan untuk budidaya ikan lele, Journal of Science, 10(April), pp. 31-35. doi: ISSN/ : 14121840.

Hermawan, T. E. S. A., Sudaryono, A. \& Prayitno, S. B. (2014). Pengaruh padat tebar berbeda terhadap pertumbuhan dan kelulushidupan benih lele (Clarias gariepinus) dalam media bioflok, Journal of Aquaculture Management and Technology, 3(3), pp. 3542. Available at: http://ejournal-s1.undip.ac.id/ index.php/jamt.

Husain, N., Putri, B. \& Supono (2014). Perbandingan karbon dan nitrogen pada sistem bioflok terhadap pertumbuhan nila merah (Oreochromis niloticus), e-Jurnal Rekayasa dan Teknologi Budidaya Perairan, III(1), pp. 343-350.

Imron, A., Sudaryono, A. \& Harwanto, D. (2014). Pengaruh rasio $\mathrm{C} / \mathrm{N}$ berbeda terhadap rasio konversi pakan dan pertumbuhan benih lele (Clarias $s p$.) dalam media bioflok, Journal of Aquaculture Management and Technology, 3(3), pp. 17-25. Available at: http://ejournal-s1.undip.ac.id/ index.php/jamt.

Irianto, H. E. \& Soesilo, I. (2007). Dukungan teknologi penyediaan produk perikanan, Seminar Nasional Hari Pangan Sedunia, pp. 1-20.

Khobir, M. L., Putra, I. \& Tang, U. M. (2016). Growth and survival rate of african catfish (Clarias gariepinus) using bioflocs technology by administering different doses of probiotic bacteria (bacillus) in the water medium of peat bog, Technology Research and Development Center, pp. 1-10.
Lumentut, H. B. \& Hartati, S. (2015). Sistem pendukung keputusan untuk memilih budidaya ikan air tawar menggunakan AF-TOPSIS, IJCCS, $9(2)$.

Mas'ud, F. (2012). Teknik pengolahan ikan lele dumbo (Clarias gariepinus) di Balai Benih Ikan (BBI) Kalen Kecamatan Kedungpring Kabupaten Lamongan, Grouper Faperik, pp. 14-32. doi: ISSN/ : 20868480.

Nuari, C. R., Supono, S., Wardiyanto, W., \& Hudaidah, S. (2016). Penambahan tepung bioflok sebagai suplemen pada pakan ikan lele sangkuriang (Clarias gariepinus). e-Jurnal Rekayasa dan Teknologi Budidaya Perairan, 4(2), 485-490.

Phulia, V., Mandal, B., Bera, A., Singh, S., Das, R., \& Jamwal, A. (2012). Factors controlling biofloc characteristics. World aquaculture, 43, 57-59.

Putri, B., Wardiyanto \& Supono (2015). Efektivitas penggunaan beberapa sumber bakteri dalam sistem bioflok terhadap keragaan ikan nila (Oreochromis niloticus), e-Jurnal Rekayasa dan Teknologi Budidaya Perairan, IV(1), pp. 433-438.

Rizal, A., Yustiati, A., Suryana, A. A. H., \& Putro, R. D. (2018). Analisis komparasi keragaan usaha budidaya ikan lele mutiara (Clarias gariepinus) dengan dan tanpa sistem bioflok. Jurnal Perikanan Unram, 8(1), 65-70.

Romadhon, I. K., Komar, N. \& Yulianingsih, R. (2013). Desain optimal pengolahan sludge padat biogas sebagai bahan baku pelet pakan ikan lele, Jurnal Bioproses Komoditas Tropis, 1(1), pp. 26-35.

Rukmana, R. (1997). Ikan nila budi daya dan prospek agribisnis. 7th edn. Yogyakarta: Penerbit Kanisius Yogyakarta.

Sari, C. A., Rinto \& Sari, D. I. (2017). Kajian sistem tata niaga ikan air tawar di Kabupaten Ogan Ilir , Provinsi Sumatera Selatan, 3(November), pp. 646652.

Septiani, N., Maharani, H. W. \& Supono (2014). Pemanfaatan bioflok dari limbah budidaya lele dumbo (Clarias gariepinus) sebagai pakan nila (Oreochromis niloticus), e-Jurnal Rekayasa dan Teknologi Budidaya Perairan, II(2), pp. 267-272. doi: ISSN/ : 2302-3600.

Sudaryati, D., Heriningsih, S. \& Rusherlistyani (2017). Peningkatan produktivitas kelompok tani ikan lele dengan teknik bioflok, Jurnal Pengabdian dan Pemberdayaan Masyarakat, 1(2), pp. 109-115. doi: ISSN/ : 2549-8347.

Sukoco, F. A., Rahardja, B. S. \& Manan, A. (2016). Pengaruh pemberian probiotik berbeda dalam sistem akuaponik terhadap FCR (Feed Convertion Ratio) dan biomassa ikan lele (Clarias sp.), Journal of Aquaculture and Fish Health, 6(1), pp. 24-31. 
Windriani, U. (2017). Budidaya ikan lele sistem bioflok. Jakarta: Direktorat Produksi Usaha Budidaya.

Yulinda, E. (2012). Analisis finansial usaha pembenihan ikan lele dumbo (Clarias gariepinus) di Kelurahan
Lembah Sari Kecamatan Rumbai Pesisir Kota Pekanbaru Provinsi Riau, Jurnal Perikanan dan Kelautan, 17(1), pp. 38-55. 